This is an Open Access article, distributed under the terms of the Creative Commons AttributionNonCommercial-ShareAlike licence (http://creativecommons.org/licenses/by-nc-sa/4.0/), which permits non-commercial re-use, distribution, and reproduction in any medium, provided the same Creative Commons licence is included and the original work is properly cited. The written permission of Cambridge University Press must be obtained for commercial re-use.

\title{
The Sandby Borg Massacre: Interpersonal Violence and the Demography of the Dead
}

\author{
Clara Alfsdotter ${ }^{1}$ [1] And Anna Kjellström ${ }^{2}$ @ \\ ${ }^{1}$ School of Cultural Studies, Linnaeus University, Kalmar, Sweden \\ ${ }^{2}$ Department of Archaeology and Classical Studies, University of Stockholm, Sweden
}

\begin{abstract}
During excavations of the Iron Age ringfort of Sandby borg (AD 400-550), the remains of twenty-six unburied bodies were encountered inside and outside the buildings. The skeletons and the archaeological record indicate that after the individuals had died the ringfort was deserted. An osteological investigation and trauma analysis were conducted according to standard anthropological protocols. The osteological analysis identified only men, but individuals of all ages were represented. Eight individuals (31 per cent) showed evidence of perimortem trauma that was sharp, blunt, and penetrating, consistent with interpersonal violence. The location of the bodies and the trauma pattern appear to indicate a massacre rather than a battle. The 'efficient trauma' distribution (i.e. minimal but effective violence), the fact that the bodies were not manipulated, combined with the archaeological context, suggest that the perpetrators were numerous and that the assault was carried out effectively. The contemporary sociopolitical situation was seemingly turbulent and the suggested motive behind the massacre was to gain power and control.
\end{abstract}

Keywords: violence, trauma, Migration period, Sandby borg, Iron Age, unburied

\section{INTRODUCTION}

The timespan between $\mathrm{AD} 400$ and 550, the so-called Migration period when the Roman empire was declining, is considered a period of social instability and political turmoil in Europe. The regions north of the Rhine and Danube were populated by various tribes, the tribes of Scandinavia each being ruled by a few elites as a result of growing social differentiation. While the written sources are few, archaeological records document widespread contact with the continent (Näsman, 1984; Lund Hansen, 1987; Fischer, 2005). This era is characterized by finds of Roman solidi and hoards of gold, not least on the island of Öland, located east of the Swedish mainland in the Baltic Sea. The remains of fifteen Iron Age ringforts (i.e. fortified villages) are still visible on Öland. These ringforts might be the result of a general change in settlement, as many settlements were abandoned during the Migration period (Stenberger, 1933; Näsman, 1988). Initial studies have shown that a massacre was carried out in the ringfort of Sandby borg, and that the victims were not buried (Victor, 2015; Alfsdotter et al., 2018) (Figure 1). The word massacre is used to describe a collective act of intentionally killing a group of people unprepared for battle. Here, we examine the violent event in general, and its victims in particular. Though it is clear that many people died during a single event at Sandby borg, the 


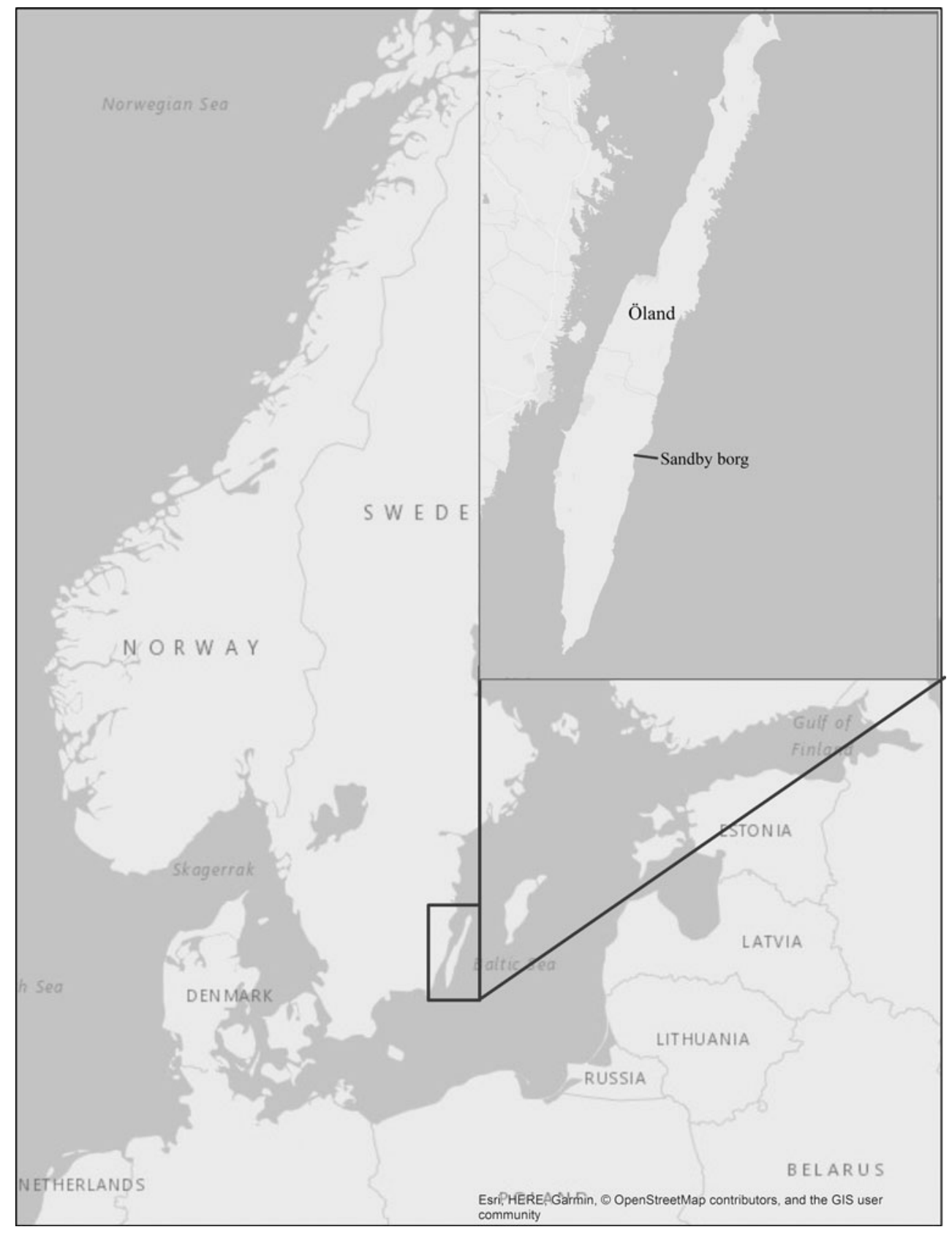

Figure 1. Map showing the location of Sandby borg, Öland, Sweden (basemap (C) OpenStreetMap contributors, modified by Helena Victor).

history behind the massacre is not known. We present the demography of the dead, the trauma patterns, the type of trauma, and the positions of the dead. Since violence is culture-specific, the results are further contextualized in an attempt to discuss the event, the perpetrators, and the possible motives that prompted the violence. 


\section{The Sandby borg ringfort}

The vast majority of artefacts found within the ringfort indicate that Sandby borg was occupied between $\mathrm{AD} 400$ and 550 (Victor, 2015; Alfsdotter et al., 2018). Since 2011, small-scale annual excavations have been carried out by Kalmar County Museum. Three houses have been fully excavated, and six partially. Additionally, parts of the street surrounding the central block have been subject to excavation (Figure 2). The excavated area amounts to a modest 9 per cent of the ringfort interior, but the results are nevertheless informative in terms of the history of the ringfort. Future excavations will clarify this further. The fort is believed to have housed 200-300 inhabitants (Victor, 2015). A mix of prestigious jewellery and everyday items was discovered in the dwellings (Victor, 2015; Gunnarsson et al., 2016). The large quantity of valuable artefacts, in association with the discovery of articulated human and animal remains, gives the impression of a 'moment frozen in time' (Alfsdotter et al., 2018). Articulated and partially scattered skeletons of humans and animals (sheep, dogs, and pigs) were found within the houses. Macro-botanical and taphonomic analyses indicate that the ringfort was not revisited after the violent attack (Heimdahl, 2014, 2016; see discussion in Alfsdotter et al., 2018; for a taphonomic discussion, see Alfsdotter \& Kjellström, in

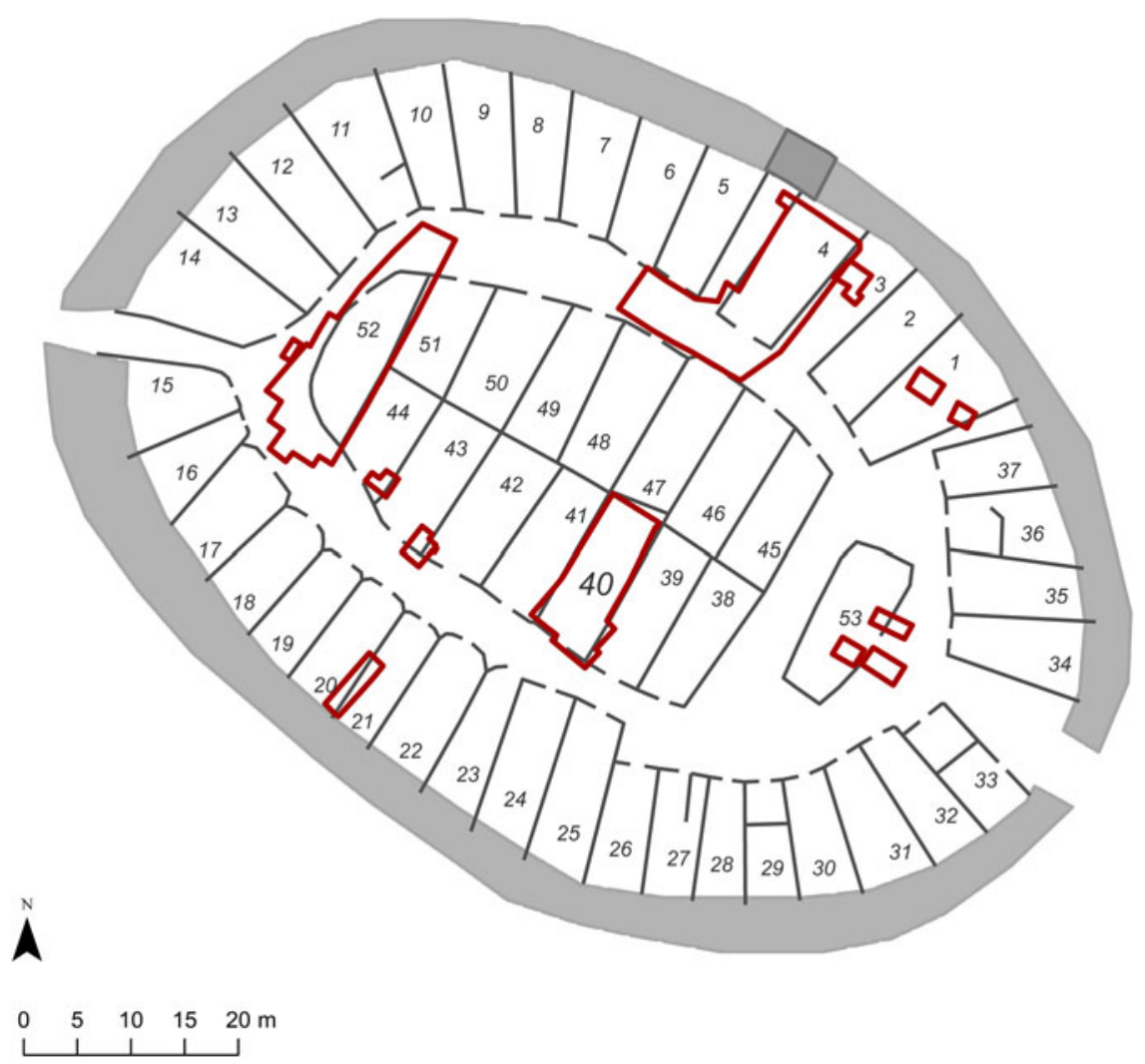

Figure 2. The internal structures of Sandby borg in accordance with geophysical prospection (Viberg 2012). Identified plausible house structures have been numbered 1-53. Marked areas have been subject to excavation. (Figure by Helena Victor.) 
preparation). The commingled skeletal remains are predominant in an outdoor environment. The archaeozoological analysis has shown that the event is likely to have taken place between late spring and early autumn (Alfsdotter in Gunnarsson et al., 2016). Recent isotopic analyses indicate that at least two of the individuals (ID1 and ID2) were probably locals (Wilhelmson, 2017: 143). For a detailed description of comparative materials, contemporary weapons, and tactics, see the online supplement (Supplementary materials 1 ).

\section{Material and Methods}

\section{Minimum number of individuals (MNI), sex, and age determinations}

Standard osteological techniques were applied for sex and age determinations of the individuals. The methods are listed in the online supplement (Supplementary materials 2). All individuals were assigned to the following age groups: fetal $=<$ birth; infant $=0-3$ years; child $=3-12$ years; adolescent $=12-20$ years; young adult $=20-35$ years; middle adult $=35-50$ years; old adult $=50+$ (Buikstra \& Ubelaker, 1994) (Table 1).

\section{Trauma analysis}

All elements were examined macroscopically and deviations implying trauma were further investigated microscopically (at a magnification of $c . \times 10-40)$. For each lesion, the size (maximum length and width), shape, and location (element, side, affected part) were recorded. Trauma was classified as antemortem or perimortem. Antemortem trauma is defined as injuries with signs of osteoblastic or osteoclastic activity implying different stages of healing such as bone remodelling (callus formation) and necrosis, or an abnormal elemental shape (i.e. inadequate fusion or pseudoarthrosis). When a fracture does not show any signs of healing in fresh bone, it is classified as a perimortem trauma, which indicates that it occurred around the time of death (Knüsel, 2005; Ubelaker, 2015). However, since the perimortem interval is related to the moisture retention of the bone, the period can be prolonged in certain environments (Kjellström \& Hamilton, 2014). Characteristics of perimortem trauma include smooth, obtuse fracture angles with the same coloration as the rest of the bone, sometimes in combination with a plastic response and distinctive fracture types described in the medical literature (Ubelaker, 2015). Perimortem trauma was further categorized according to type: sharp force trauma (SFT), puncture trauma (PT), and blunt force trauma (BFT). SFT are injuries (incisions, stab wounds, or chop wounds) sustained from a sharp object which leaves linear marks, $\mathrm{V}$-shaped in cross section, and a smooth kerf wall (sometimes showing striae perpendicular to the kerf floor) (Reichs, 1998). The kerf features, such as the angle of entry and stria may indicate the direction of the blow (Boylston, 2000). If the sharp force lesion that penetrated the tissue is deeper than it is wide, indicating that it was caused by a sharp, pointed object, the lesion is classified as puncture trauma (PT). BFT are injuries (tear or crush fractures) caused by broad objects which, except for the immediate site of impact, can involve radiating and concentric fractures (Berryman \& Symes, 1998). For both SFT and BFT, the location, size, and shape were recorded. Given the poor preservation and the complexity of the varying contexts (i.e. several houses and the street) in which the bones were recovered, the crude prevalence was used to estimate the number of trauma per affected individual (in comparison with true prevalence where the estimation acknowledges 
Table 1. Preservation, demographic distribution, and trauma in relation to context (AT $=$ antemortem trauma; $P T=$ perimortem trauma; $F=$ find number, used for elements without clear association to a unique individual).

\begin{tabular}{|c|c|c|c|c|c|}
\hline ID & $\begin{array}{l}\text { Majority of skeleton } \\
\text { articulated (in brackets, } \\
\text { per cent of skeleton preserved) }\end{array}$ & Age group (years) & Sex & Trauma & Context \\
\hline 1 & Yes (100) & Adolescent (17-19) & Male & $\mathrm{PT}+\mathrm{AT}$ & House 40 \\
\hline 2 & Yes $(100)$ & Young adult (19-25) & Male & PT & House 40 \\
\hline 3 & No $(20)$ & Middle adult & & PT & House 40 \\
\hline 4 & Yes (75) & Young adult & Male? & $\mathrm{PT}+\mathrm{AT}$ & House 40 \\
\hline 5 & Yes $(60)$ & Young(?) adult & Male & & House 40 \\
\hline 6 & Yes (90) & Adolescent (12-15) & & PT & House 40 \\
\hline 7 & Yes (100) & Adolescent (12-15) & & & House 40 \\
\hline 8 & No (5) & Infant/Child (2-5) & & & House 40 \\
\hline 9 & Yes (85) & Old adult & Male & & House 52 \\
\hline 10 & No (5) & Infant & & & House 52 \\
\hline 11 & No $(5)$ & Middle adult & & & House 52 (pit 4) \\
\hline 12 & Yes (80) & Child (6-8) & & & House 4 \\
\hline 13 & No (40) & Adolescent (10-13) & & PT & House 4 \\
\hline 14 & No (20) & Old(?) adult & & PT & House 4 \\
\hline 15 & No $(75)$ & Old adult & Male & & House 4 \\
\hline 16 & No (20) & Middle adult & & & Street \\
\hline 17 & No $(5)$ & Child (5-9) & & & Street/alley \\
\hline 18 & No (30) & Young adult (20-25) & & & Alley \\
\hline 19 & No (20) & Old adult & Male & & Alley \\
\hline 20 & No (5) & Child (3.5-6.5) & & & Street/alley \\
\hline 21 & No $(25)$ & Adolescent (12-15) & & & Street \\
\hline 22 & No $(5)$ & Child (3.5-6.5) & & & Street \\
\hline 23 & No (20) & Young adult (20-25) & Male? & PT & Street \\
\hline 24 & No (20) & Middle adult & Male & & House 3 \\
\hline 25 & No $(5)$ & Infant (1.5-3 months) & & & House 40 \\
\hline 26 & No (5) & Infant $(2-4)$ & & & House 3 \\
\hline F6671/F6141 & No (1) & Adult & & AT & House 40 \\
\hline
\end{tabular}

the preservation of different elements). This means that it is likely that the identified injuries are only a minimum representation of the full extent of the original trauma.

\section{RESULTS}

A minimum of twenty-six individuals was identified (House 3: two individuals; House 4: four; House 40: nine; House 52: three; Street: eight) (see Figures $5 \mathrm{~A}$ and $B)$. The age distribution is varied: the youngest individual (ID25) was an infant 1.5-3 months old and the two oldest individuals (ID9 and ID15) were over 50 years old. The nine adults with sufficiently preserved morphological traits to determine biological sex exhibit male characteristics. The sex of the children is unknown. The sample size was too limited to identify any demographic patterning on the 
site; but, in the house with the most bodies (House 40), all age groups were represented, from infants to old adults. Similarly, children, teenagers, and adults were also discovered in the street.

Perimortem trauma was identified in eight individuals (Table 2) (Figure 3 and 4):

ID1: the skeleton of a male adolescent, was found in a supine position in House 40. The humeri were abducted (c. 30 $)$ and the lower limbs flexed at the knees. SFT was identified on the right scapula and the cranium together with a circular defect, likely to be a PT, on the right femur. The linear scapula lesion is located diagonally over the acromion and extends into the corpus in posterior view, left superior to right inferior (c. $110^{\circ}$ to the sagittal plane). Fragmentation prevents us from determining the maximum length. The SFT on the left parietal runs from just below the sagittal suture towards the squamous suture, aligned to the frontal plane (Figure 4A). The cut measures $102 \mathrm{~mm}$ and penetrates the tabula interna. The kerf wall is primarily visible on the posterior part in the superior section of the wound and on the anterior part in the inferior section. The smooth femoral circular defect measures
$7 \times 8 \mathrm{~mm}$ and is located on the distallateral part of the shaft.

ID2: the skeleton of a young adult male, was lying in a prone extended position in House 40. The cranium presented its left posterior-lateral side and was lying adjacent to the left hip and lower thorax of ID1. The left upper limb was abducted, rotated medially, and slightly flexed at the elbow, with the forearm pronated. The right upper limb was slightly abducted, rotated medially, and projected posteriorly. The PT identified consists of a rhombic puncture wound of the central occipital, just above the external occipital protuberance. The injury, $7.3 \mathrm{~mm}$ in length, penetrated the outer table and diploë but not the tabula interna. (In a preliminary analysis, SFT on a rib and a tooth of ID 2 was suggested by Wilhelmson (2017) but this could not be confirmed in the present analysis.)

ID3: the skeleton of a middle adult individual, was found disarticulated in House 40. Adjacent to a fragmented cranium, presenting its lateral right aspect, a radius and a humerus were found. An articulated tibia, fibula, and a foot were encountered 1.2 metres to the north.

Table 2. Perimortem trauma identified $(R=$ right, $L=$ left. $S F T=$ sharp force trauma; $P T=$ puncturing trauma; $B F T=$ blunt force trauma).

\begin{tabular}{|c|c|c|c|c|}
\hline ID & Element & Side & Trauma & Description \\
\hline 1 & parietal & $\mathrm{L}$ & SFT & Linear lesion $(102 \mathrm{~mm})$ on central section \\
\hline 1 & scapula & $\mathrm{R}$ & SFT & Linear lesion $(30 \mathrm{~mm})$ diagonally in acromion and corpus \\
\hline 1 & femur & $\mathrm{R}$ & PT & Circular lesion $(7 \times 8 \mathrm{~mm})$ on lateral-distal shaft \\
\hline 2 & occipital & central & PT & Rhombic lesion $(4.3 \times 7.3 \mathrm{~mm})$ in central section \\
\hline 3 & parietal & $\mathrm{L}$ & SFT & Linear lesion (50 mm kerf wall) on central section \\
\hline 3 & frontal & $\mathrm{R}$ & SFT & Linear lesion $(>30 \mathrm{~mm})$ on medial section \\
\hline 4 & occipital & $\mathrm{R}$ & SFT & Linear lesions (both fragments $>16 \mathrm{~mm}$ ) lateral occipital \\
\hline 6 & parietal & $\mathrm{R}$ & BFT & Circular lesion $(36 \times 29 \mathrm{~mm}$ in diameter $)$ on central section \\
\hline 13 & $\begin{array}{l}\text { cervical vertebra } \\
\quad(\mathrm{C} 3-5 ?)\end{array}$ & corpus & SFT & Linear horizontal lesion (right: $10 \mathrm{~mm}+$ left: $22 \mathrm{~mm}$ ) through lamina \\
\hline 14 & parietal & $\mathrm{L}$ & BFT? & Horizontal convex lesion ( $>24 \mathrm{~mm}$ ) on central section \\
\hline 23 & ilium & $\mathrm{L}$ & SFT & Linear lesion $(19 x>19 \mathrm{~mm})$ through arc composé \\
\hline
\end{tabular}



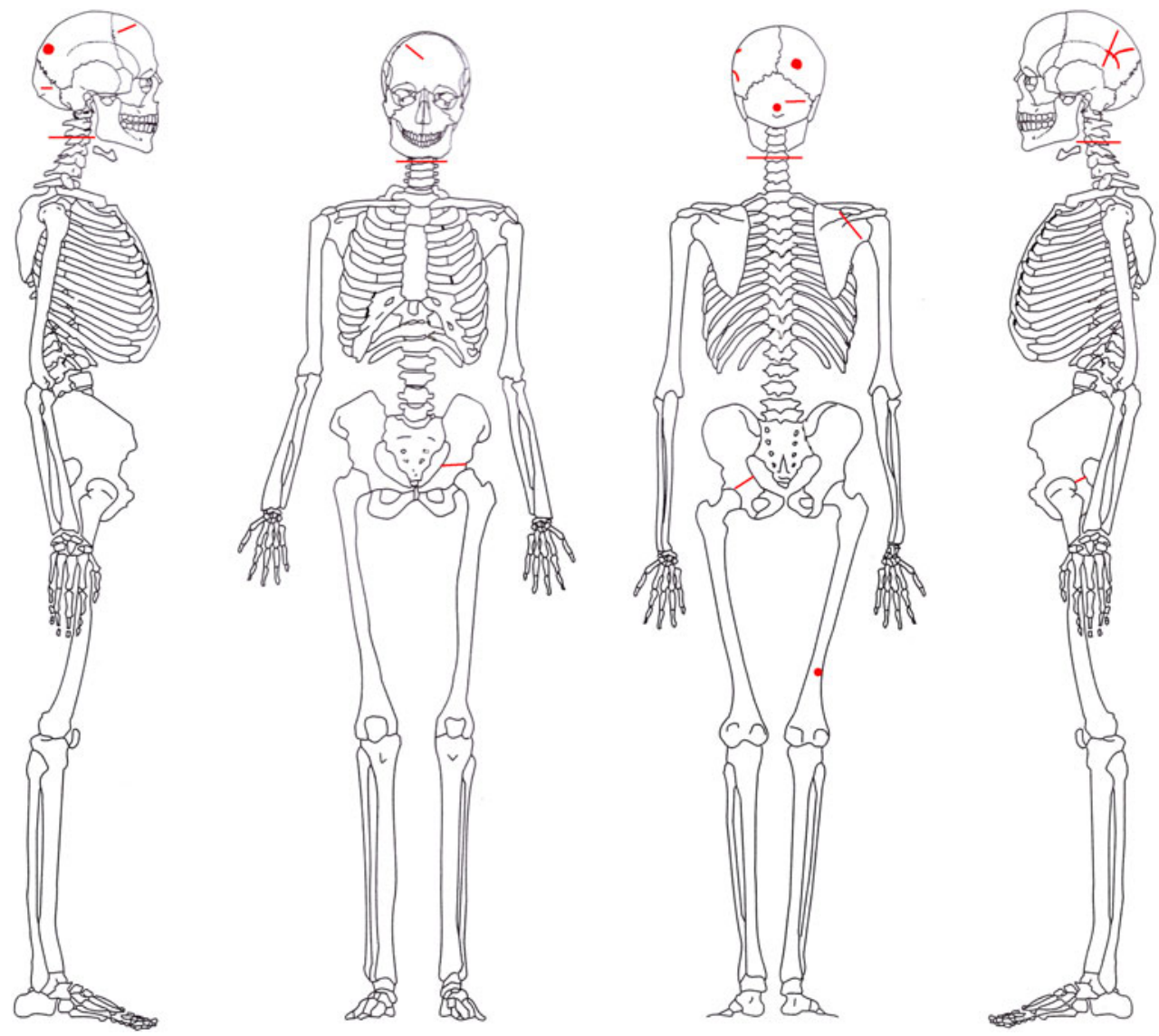

Figure 3. Distribution of perimortem trauma of all the victims. One lesion to the occipital bone of ID4 is not included, as the exact location could not be established (original illustration by Buikstra छ Ubelaker, 1994, modifications by Alfsdotter and Kjellström).

However, it cannot be established whether the latter unit of elements belong to the same individual as the cranium. The subsection of the house (House 40) where the individual was discovered contained several skeletons with partial postmortem disarticulation, likely to have resulted from the partial destruction of the roof following a fire associated with the assault (Alfsdotter \& Kjellström, in preparation). SFT to the centre of the left parietal was identified, in lateral view the injury radiates right superior to left inferior. The kerf wall is primarily on the anterior side, the posterior fracture surface is rough. A perimortal secondary fracture radiates posteriorly. A second SFT of the medial right part of the frontal bone was identified. In frontal view, the cut runs from left superior to right inferior $\left(c .45^{\circ}\right)$. The maximum length of the injury is unknown as fragments are missing bilaterally. The cut has penetrated tabula interna.

ID4: the highly fragmented skeleton of a young adult, was encountered in House 40 in a prone extended position with the right upper limb extended and the left upper limb flexed, with the hand under the left shoulder. The positioning of the cranium could not be established. The 

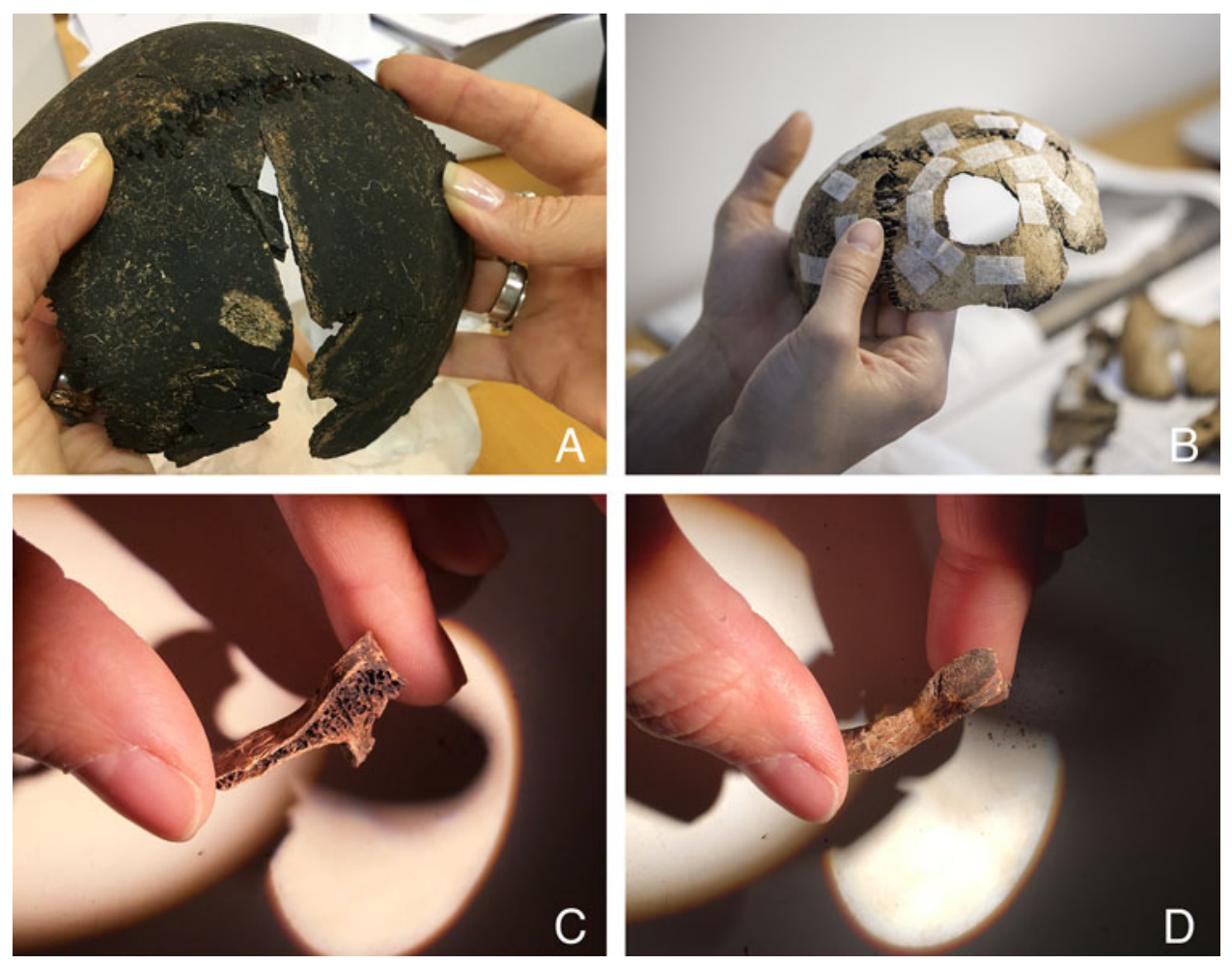

Figure 4. A: Sharp force trauma on the left parietal bone of individual ID2. B: Blunt force trauma on the right parietal bone of a young teenager (ID6) (photograph by Daniel Lindskog). C-D: The skeleton of a 10-13 years old adolescent (ID13) shows evidence of decapitation. Sharp force trauma is visible on a cervical vertebra.

skeleton was slightly rotated towards the right, judging from the position of the thorax and the pelvis. The femora were extended. All bones inferior of femora were missing (this might be the result of a disturbance in form of an earlier archaeological trench). The calvarium was fragmented and scattered. Two sharp force injuries (both at least $16 \mathrm{~mm}$ in length) were identified on the right side of the occipital. Due to fragmentation, the exact location of only one of the lesions could be established. The injury radiates horizontally in posterior view and has probably crossed the lambdoid suture on the right side. The angle of the cut in relation to the horizontal plane is $c .20^{\circ}$ and striae are visible radiating diagonally, indicating a blow aimed from the lower right. The other lesion could be part of the same traumatic incident, but it could also be the result of a different blow. It cannot be established whether the cuts penetrated the tabula interna, as the diploë is fragmented.

ID6: the skeleton of an adolescent, was found in House 40 in a supine extended position with the left upper limb and the lower limbs extended. The right upper limb was partially missing. The cranium was fragmented but presented its lateral right side. The vertebral column shows a postmortem dislocation between $\mathrm{T} 12$ and L1. The feet were partly on top of the hip of ID5, whose hand bones were discovered under the left fibula of ID6, implying that 
ID6 fell after ID5. The cranium of ID6 displays BFT of the right parietal bone (Figure 4B). Just medially of the parietal tuber, a circular injury $(36 \times 29 \mathrm{~mm})$ with internal bevelling was observed. At least five secondary fractures radiate from the point of impact. All showed perimortem characteristics but only three of these ends at the lambdoid suture. Two of the fractures continue across the lambdoid suture, indicating a postmortem origin (Berryman \& Symes, 1998).

ID13: consists of disarticulated bones that are seemingly from the same young adolescent. They were found in front of the entrance of House 4 (Alfsdotter, in press). Two bones display gnawing from a rodent. SFT was noted on two vertebral arch fragments from the cervical region of the vertebral column. One of the fragments, the right superior articular process and part of the lamina, exhibited a linear horizontal cut angled inferiorly and radiating laterally-medially (Figure 4C, 4D). The inferior part of the right side of the vertebrae is missing. The second arcus fragment (inferior articular process and lamina) displaying SFT is from the left side. The lesion is similar to the first fragment, a horizontal cut, but the kerf wall has another angle (superior rather than inferior). Since both fragments lack antagonists and striation of the cut surfaces, it cannot be ruled out that the traumas are the result of the same blow.
The vertebra(e) affected is between C3 and $\mathrm{C} 5$. The mandibula of the individual was not affected.

ID14: the remains of another predominantly disarticulated skeleton of an older individual, were found in front of the entrance of House 4. A fragment of the left parietal displayed perimortal BFT. Centrally on the element, above the squamous suture, a horizontal convex fracture radiates. The injury is funnel-shaped, internal bevelling is visible, and the fracture surface of the tabula externa is smooth. The preserved part of the fracture measures $24 \mathrm{~mm}$ medio-laterally. However, the anterior extension of the fracture is missing. From the posterior end of the fracture, a postmortal fracture radiates towards the lambda.

ID23: On the street, a fragment of a left ilium from a young adult displaying SFT was found. The injury is located next to the auricular surface, through the composite arch. The recovered cut surface measures $19 \times 19 \mathrm{~mm}$. In lateral view, the injury radiates from right superior to left inferior, of the ilium (at an angle of $c .40^{\circ}$ to the sagittal plane). The bone is fractured anteriorly, hindering analysis of the full extent of the trauma. No antagonist is present. The weapon seems to have penetrated the lateral aspect of the acetabulum and cut the entire left side gluteus muscles.

There are few antemortem injuries (Table 3). Healed fractures were

Table 3. Antemortem trauma identified ( $F=$ find number, used for elements without clear association to a unique individual; $R=$ right, $L=$ left $)$.

\begin{tabular}{lllll}
\hline ID & Element & Side & Trauma & Description \\
\hline 1 & scapula & $\mathrm{R}$ & Fracture? & Separation of coracoid \\
1 & ribs & $\mathrm{R}+\mathrm{L}$ & Fractures & Posterior corpus, $>2$ fractures right side and $>3$ left \\
2 & metacarpal V & $\mathrm{R}+\mathrm{L}$ & Fractures? & Bilateral swelling of shafts \\
4 & humerus & $\mathrm{R}$ & Fracture & Spiral fracture of proximal shaft \\
4 & clavicle & $\mathrm{L}$ & Pseudoarthrosis & On costal tuberosity, inferior-posterior on sternal end \\
F6671/F6141 & neurocranium & & Fracture & Circular depression (15 mm in diameter). \\
\hline
\end{tabular}


documented in three, or possibly four, individuals. Two individuals (ID1 and ID4, both found in House 40) show traces of two injuries each. The first (ID1), an adolescent around 17-19 years old, showed a separation of the right coracoid of the scapula and callus formation on the posterior section of the ribs from both sides (a minimum of 2 right and 3 left), most likely caused by direct trauma (i.e. through force transmitted at a right angle). As for the second individual (ID4), the right humerus exhibited a malalignment of the proximal humeral diaphysis and a pseudoarthrosis in the sternal end of the left clavicular diaphysis, indicating oblique or spiral fractures and indirect trauma. In addition, a neurocranial fragment still not allocated to a skeleton (F6671/F6141, House 40) had a healed, circular depressed fracture measuring $15 \mathrm{~mm}$ in diameter. ID2, again from House 40, shows possible trauma-induced anomalies bilaterally on the lateral aspects of the shafts of the fifth metacarpals. The projecting bone growth takes the same form on both sides but is located slightly superior on the left side. The appearance of the bone anomalies bears some resemblance to boxer's fractures (i.e. a fracture of the fifth metacarpal due to the direct impact of a clenched fist with a person or object). The bilateral presence makes a traumatic cause less likely, though not impossible. An alternative explanation could be a congenital malformation.

\section{Discussion}

The unhealed sharp force lesions are consistent with interpersonal violence. Furthermore, the location of the two cases of blunt trauma, above the hat brim line, suggests that the individuals were subjected to aggressive acts rather than accidental falls or similar mishaps (Kremer \& Sauvageau, 2009; Guyomarch et al.,
2010). The investigation showed that eight of twenty-six individuals exhibit perimortem trauma. This means that at least 31 per cent were subject to violent acts near the time of death. In comparison, if we look at only cranial blade wounds, 96 per cent of the men from the Battle of Towton (England, War of the Roses, AD 1461; Novak, 2000), 60 per cent from the Battle of Good Friday at Uppsala in AD 1520 (Kjellström, 2005), 90 per cent from medieval Sandbjerget (Næstved, Denmark; Bennike, 1998), and 40 per cent at the Battle of Wisby in AD 1361 on Gotland (Ingelmark, 1939) were affected. However, the comparison is impaired by a number of factors: these comparative data are not only of a later date, but they represent a completely different composition of people, who were often trained for battle, died in battle, and were subsequently buried. The human remains excavated at the Iron Age hillfort of Fin Cop (Derbyshire, England) are a better comparison in terms of date $(c$. $300 \mathrm{BC}$ ), type of violence encountered, and deposition of bodies. At Fin Cop, the remains of fifteen individuals (women, adolescents, and newborn/unborn children) were found in a ditch together with debris from the demolition of the hillfort (Waddington et al., 2012). Some skeletons were articulated and others commingled. Despite the low amount of perimortem injury (only one confirmed), the cause of death of the individuals is believed to have been interpersonal violence. This interpretation is based on the manner of interment, with bodies thrown into the ditch at the time of the hillfort's destruction. The researchers suggest that the manner of death was probably soft-tissue wounds that left no skeletal marks (Waddington et al., 2012: 226). As at Sandby borg, only a small part of the whole site has been excavated and the number of individuals is likely to have been much greater at both sites. The unburied corpses in Sandby borg 
were exposed to the weather, animals, insects, and house debris (such as that from stone walls, wooden beams and turf roofs), leaving the skeletal material fragmented. It should be noted that most of the individuals found in Sandby borg only comprise a few bone units, sometimes only teeth, as the human remains recovered from the street are commingled and have been subject to vast taphonomic degradation (Table 1). The nature of the skeletal remains gives us reason to believe that traumatic lesions inflicted on several bodies have not been identified. Although the number of perimortem traumatic injuries encountered in Sandby borg is comparatively low, it is their connection with the sample's demographic aspects and body positions that enable us to attempt a reconstruction of the course of events and the underlying motive.

\section{How? the perimortem trauma pattern}

By studying the positions of the unburied skeletons at Sandby borg in tandem with the perimortem trauma, it is possible to obtain additional information about the modus operandi of the perpetrators.

In total, eleven perimortem lesions were identified in eight individuals. Sharp force trauma was documented in seven cases, blunt force was used in two cases, and puncture wounds were caused in two cases (Table 2). Two individuals (ID1 and ID3) suffered at least two sharp force blows. Bones of the cranium were the most affected, suggesting that this was the primary target, but postcranial wounds were noted in the neck (cervical vertebra (e)), shoulder (scapula), and hip region (the ilium) of the individuals, with no preference as to which side of the body. The blunt injuries were located on the top of the head, near the sagittal suture, whereas the wounds inflicted by sharp objects varied in location and direction. Of the eleven perimortem lesions identified, five were aimed at the back of the body (scapula, ilium, femur, and two on the occipital) of the victims, implying that they were attacked from behind. The trauma identified in the cervical region of ID13 could perhaps also be included in this group. The lesions on top of the cranium of at least ID1 may indicate that the individual was in a lower position in relation to the perpetrator, or that the latter was on horseback (that scenario is however very unlikely given that the skeleton was found indoors ${ }^{1}$ ). Only two of the lesions (on ID 3 and ID14) are consistent with battle wounds that could be expected in face-to-face combat with a righthanded assailant (Larsen, 1999: 157). However, there might be an underrepresentation of facial trauma identified since the preservation of the delicate facial bones was poor. Characteristic defence injuries, such as parry fractures on the forearms or hands, or sharp incisions on the palmar aspect of the finger bones, are missing (Dolinak et al., 2005: 149-50).

Moreover, the bodies of the remaining individuals who do not have observable perimortem lesions were also found in the dwellings and in the street (Figure 5). They were discovered in a flexed position (ID7, figure 5A) and lying extended, both prone (ID9) and supine (ID 5 and ID12, the latter in figure 5B), and possibly sitting (ID15). In one case, individuals had fallen over each other (Alfsdotter

\footnotetext{
${ }^{1}$ The body seems not to have been arranged in a formal position but was likely left behind after the assault. The remains of nine individuals in house 40 follow no pattern in terms of skeletal position or postmortem treatment. In House 52, a skeleton (ID9) was lying prone across a hearth. Parts of his skeleton were charred, a testimony to the hearth having been lit as the man fell(?) over it never to rise again. The Sandby borg context so far indicates a rapid killing with no or limited handling of the dead bodies (the taphonomy is further discussed in Alfsdotter \& Kjellström, in preparation).
} 

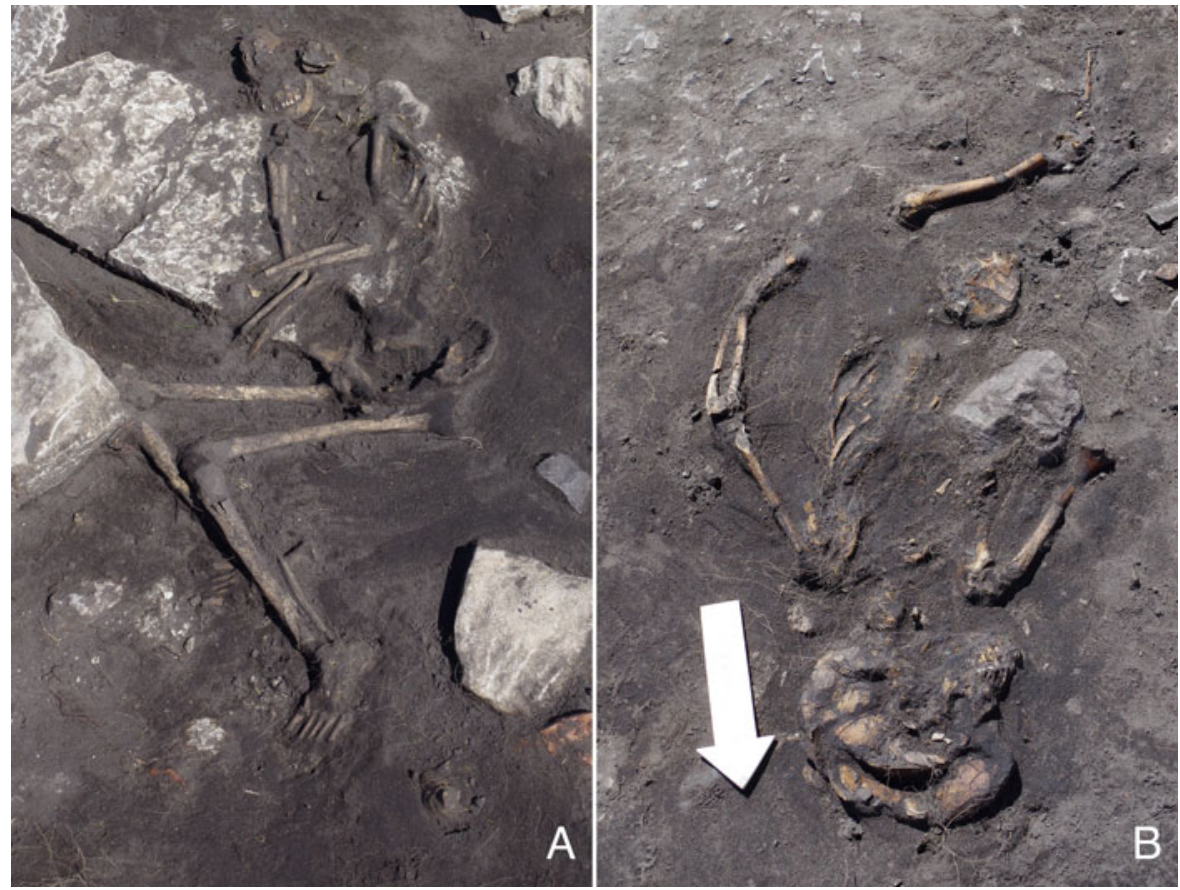

Figure 5. A: The articulated skeleton of ID7, an adolescent, is one of nine individuals whose remains bave been found inside House 40. B: The partially articulated skeleton of a child (ID12) excavated in House 4.

et al., 2018). An older man (ID9) was lying face down diagonally over the central hearth of House 52. The anterior pelvic region was partially charred, suggesting that the fireplace was still burning, or at least smouldering, when the man fell (Papmehl-Dufay \& Alfsdotter, 2016).

Although the number of identified injuries is low, the varied distribution lacks patterning, which implies that the victims did not carry any protective gear (this is hardly surprising given the demographic spread). This is in line with the general impression that the inhabitants were taken off guard. If the trauma analysis is representative of a massacre, the preferred weapon of the assailants was the sword. It is not possible to rule out axes; but, as none of the sharp force lesions exhibit the fracture pattern expected from a combination of sharp and blunt force trauma caused by an axe (Reichs, 1998), swords were most likely to have been the weapon used. The penetrating lesion did not have enough characteristic traits to identify the weapon type, and could have been caused by any sharp, pointed weapon (such as a spear or lance) or other object. The same goes for the blunt force traumatic injuries.

By combining the perimortem lesions with body positions, it may be possible to establish the circumstances surrounding the deaths of certain individuals. The supine skeleton of individual ID1 had three injuries where the sharp force trauma on the scapula must have severed the muscles of the right rotator cuff (teres minor, supraspinatus and infraspinatus). This impaired the stability and movement of the shoulder and upper limb. The blow does not seem to have penetrated the posterior thorax. The penetrating wound on 
ID1's femur could, in a similar way, have damaged muscles and tendons (musculus biceps femoris and tractus iliotibialis). Both lesions must have led to blood loss but need not have been lethal. The cranium, however, shows a wound which penetrated the inner table of the parietal bone, exposing the brain tissue. The sequence of the lesions is hypothetical, but it is likely that the blow to the back and thigh preceded that on the head since the latter caused severe cranial damage which could, in itself, have resulted in the death of the man. Consequently, it is possible that the man managed to survive an initial blow, before being struck on the head and falling on his back. In another house, the skeleton of the 10-13 year old adolescent (ID13) had SFT in the neck region. Though the cervical vertebra(e) are severely fragmented, it is clear that at least one horizontal blow cut through the soft tissue and penetrated the medulla, which would have damaged major arteries (posterior inferior cerebellar artery and possibly anterior spinal artery). The cut(s) are likely to have led to the instant death of the individual at the site where the human remains were discovered (if they were not moved secondarily). These two case studies suggest that, at one point, the wounded shared space with the dead and dying, illustrating a chaotic situation with people in a state of shock. Perhaps ID1, who died just inside the entrance of House 40, was wounded in the street, after which he entered the house (for shelter?) where he then received the final blow to his head.

\section{Who? trauma and demography}

The isotopic data (Wilhelmson, 2017) indicate that at least two of the Sandby borg victims grew up in the region. Whether this is true for the rest of the group is not yet known, but it is likely that the youngest victims of the massacre were born on the island. Moreover, it is probable that all the victims were local inhabitants. Only male remains have been identified among the adults for whom sex could be determined. The presence of an infant and young children, and the finds of female attire (Magnus, 1997, 2002), imply that women lived within the walls. Within the bioarchaeological field, there are examples where a biased sex distribution (with no or few women) in a skeletal collection has been interpreted as raiding for women and girls. This practice is not uncommon in attacks on small settlements (e.g. Kohler \& Kramer Turner, 2006; Cameron, 2013; Martin \& Harrod, 2015). Although the main purpose of the attack was not necessarily to take prisoners, the kidnap of women may have been an added benefit. They could be taken as wives, used as extra labour, or sold as slaves (e.g. Martin et al., 2010). However, since only a small part (c. 9 per cent) of the ringfort has been excavated, the absence of female remains could be a coincidence, and we must be wary of over-interpreting this aspect. It should also be stressed that the sex distribution among the children is yet to be established through DNA analysis. Nevertheless, it is not uncommon that women are treated differently in massacres, and perhaps the female remains are to be discovered in another part of the ringfort.

If we consider the taking of slaves as a possible reason behind the attack, this is complicated by the presence of children and teenagers, who we may assume were easy prey. Could the children have taken part in the battle? Little is known about the socialization processes of children during the period, and it is not clear when a child was considered to have become an adult. The transition from childhood into adulthood was likely to have been based on physical and mental maturity, but 
could also be connected to the social status of the individual (Mejsholm, 2009: 24). For boys, it could be associated with a time when the youth was physically fit for weapon training. The youngest individuals at Sandby borg with documented perimortem injuries were the decapitated 10-13 year old adolescent (ID13), and a 12-15 year old (ID6) with a blunt force lesion to the right parietal (Tables 1 and 2). The sexes are not known, and it is not clear whether these individuals were passive victims or if they put up armed resistance. Attempts to identify active engagement of non-adults in violent encounters have been made in prehistoric skeletal assemblages (Fibiger, 2014). Adolescents of similar age to those found in Sandby borg were assessed as having probably participated in armed conflict in early medieval Ireland (Geber, 2015). Even if this were the case with the two young individuals from Sandby borg, the younger children were either deliberately killed (but without lesions identified) or left to die. This indicates that the killings were indiscriminate with regard to age. Furthermore, the young individuals (twelve of the twenty-six individuals were younger than 15 years old) could not, if we disregard the signs of visible trauma, have had much, or any, battle experience. At the other end of the age spectrum, there were three men older than 50, none of whom had identifiable antemortem or perimortem wounds. Both groups could be seen as 'atypical warriors'.

The remaining group $(n=12)$ of young or adults in the category 'middle adult' may be considered able-bodied and fit for fighting. Indeed, it is this group that exhibits the highest number of perimortem lesions, and it is tempting to interpret these visible weapon wounds as indicative of a more active resistance to the attack. However, the biased distribution of wounds could be due to preservation factors. At any rate, only one or two individuals in this group (ID1 and F6671) show signs of healed direct fractures, and the number of antemortem traumatic injuries was generally modest in the Sandby borg skeletons. The prevalence is similar to that found in contemporary cemetery populations. For instance, c. 8 per cent of the individuals (both men and women) in the Migration-period cemetery of Prague-Zliín, Czech Republic, showed traces of healed traumatic lesions (Vargová et al., 2016). A high frequency of antemortem trauma may indicate previous battle experience. In the study of the skeletal remains from the Battle of Towton (England), for instance, at least 32 per cent of the crania exhibited healed, weapon related lesions, implying experience of previous encounters (Novak, 2000). Overall, the demographic composition, along with the trauma pattern, shows that most individuals exhumed in Sandby borg had little chance to defend themselves, and that only a few are likely to have had battle experience. Although grown men were probably the primary target group, all members in the Sandby borg community seem to have been subjected to violence, and non-combatants could at least be considered collateral damage (see Tegtmeyer \& Martin, 2017). The deliberate killing or abandonment of young children further suggests that the intention of the attack was to annihilate the inhabitants. Though it is possible that some of the fallen adult men belonged to the attackers, it appears unlikely that the assailants would have left any of their own behind, as the victorious group in a battle normally has the opportunity to tend to their dead.

Does the trauma pattern at Sandby borg and the identification of weapon injuries reveal anything about the assailants? It has been suggested that Scandinavian men could have received military training in the Roman Empire (Nicklasson, 1997: 173; 
see online supplement: Supplementary Material 1). At least in theory, formal training with weapons could lead to 'standardized' violence, a recognizable pattern with regard to injuries sustained by the victims. However, no such injury pattern was discernible, since the small size of the sample and the poor preservation of the remains has affected the outcome of the analysis. Given the few perimortem traumatic injuries identified, the same can be said about the primary choice of weapon, thought to be the sword. In close combat, this is the most effective weapon; but, as discussed, other types of weapons, pointed, edged, or blunt, could also have been used.

\section{Why? contextualization of trauma and the inhabitants of Sandby borg}

Martin and Harrod write that massacres (i.e. multiple killings of all age groups and of both sexes) can be seen as a political instrument that is '[...] often used by perpetrators to either subjugate or eradicate a group defined as having cultural characteristics that separate them in some way from the aggressors' (Martin \& Harrod, 2015: 129). Since interpersonal violence is seldom random, it allows the perpetrators to gain control over land or other groups. The competition for women can be a contributing factor behind conflicts in both prehistoric and present-day small-scale societies (Sanderson, 2014: 291-96); although groups demonstrate a great variability regarding the causes of violence (McCall \& Shields, 2008). Furthermore, massacres are part of complex processes, not only because they imply planning and the involvement of many people, but also because they operate at a sociopolitical and cultural level. Environmental stress factors and risk of losing resources could also be a motivating factor for violence (Ember \&
Ember, 1997). Studies of different geographical regions, dating from 10,000 $\mathrm{BC}$ to today, have shown that there is a strong relationship between climate change and intergroup conflict (Hsiang et al., 2013). This is interesting, since tree ring data has shown that the period $A D$ 450-550 in Europe was a time of climatic changes (Büntgen et al., 2011). It is difficult to establish to what degree a small-scale society like that at Sandby borg would have been affected by fluctuations in temperature and precipitation and what specific social stress factors could have led to the Sandby borg massacre. A combination of several factors was probably at play.

A change in settlement pattern can be seen in Scandinavia during the Migration period, where several settlements were abandoned or destroyed. This has been interpreted as a socioeconomic crisis, possibly related to changing political structures in the aftermath of the fall of the Western Roman Empire (e.g. Stenberger, 1933; Näsman, 1988; Fischer, 2005; Heather, 2006; Hedeager, 2011; see also discussion in Alfsdotter et al., 2018). The presence of dead children at Sandby borg may be indicative of extraordinary circumstances. Non-accidental perimortem injuries documented among young children from the fourth-fifth-century AD cemetery of Lisieux in Normandy in France have previously been interpreted as the result of social stress caused by political disturbances and perhaps raiding groups (Timmins et al., 2017). In another study, in the context of the fifteenth-century massacre of Cepin in Croatia, bioarchaeological results were used to identify the causative agent behind a specific raid, and to differentiate attempts to take prisoners of war from attempts to strategically spread fear and panic in a population (Slaus et al., 2010). Judging from the current analysis of the Sandby borg assault, it is unlikely that the massacre was 
the result of an attempt to obtain wealth, since potential prisoners (e.g. children), luxury items, and animals were left behind. Theoretically, the attack on Sandby borg could have been some form of retribution. In discussing violent behaviour and its aftermath during the Iron Age in Scandinavia, Lindbom (2006: xviii) suggests that an attack on a farm (i.e. attacking people in their home) was an extreme act with dire consequences. The attackers were consequently forced to kill everyone to eliminate witnesses and, thus, avoid being subjected to vengeance. So far, there is no archaeological or osteological evidence of feuding between Sandby borg and other local groups (e.g. evidence of burning in cultural layers caused by previous fires, large collections of weapons, or healed weapon-related trauma).

In skeletal series associated with contexts similar to those of Sandby borg, bioarchaeological analyses have revealed information about the extent of the violence. In well-known cases of attacks on villagers in other periods and geographical regions, documented for example on prehistoric and historic sites in the US, dreadful acts of violence, such as mutilation and trophy-taking, have been documented (e.g. Owsley et al., 1977; Willey, 1990; Andrushko et al., 2005). Acts of body processing in a ritual or sacrificial manner have also been observed in Iron Age wetland contexts, showing that postmortem manipulation of human bodies was not a completely uncommon or extreme behaviour (see Supplementary Material 1). However, the scene at Sandby borg suggests a different situation. The attack appears to have been an expedient and brutal affair. The villagers were seemingly taken by surprise rather than engaged in a conventional battle. Although it is impossible to say anything about how much has been plundered, the perpetrators do not appear to have been very interested in staying and searching for loot, considering the quantity of jewellery and other luxury items found during the excavations. The injury pattern and the positions of the bodies is another indication of a brief attack. The victims do not have the appearance of having been moved after they died, and the injuries are almost 'efficiently' distributed, in the sense that only the minimum amount of violence necessary to kill was used (for a taphonomic analysis, see Alfsdotter \& Kjellström, in preparation). The comparatively few instances of perimortem fractures (even in the rather complete skeletons, e.g. ID7 and ID12) suggest that each victim was overcome with a minimum of effort by the attacker. The injury pattern and reconstructed body positions also indicate that the victims' bodies were not further brutalized or manipulated after death. Furthermore, the repeated pattern, with dead humans inside and outside several houses, suggests that the perpetrators were numerous and coordinated.

Dutton et al. (2005) explored the varying motives behind massacres and genocides during the twentieth century. Although the social systems of modern states and small Iron Age chiefdoms differ greatly, some arguments put forward in this study may be pertinent to the discussion of the motives behind the Sandby borg massacre. A common denominator of mass killings is that the perpetrating group perceives the target group as having obtained some form of unfair advantage. Historical and political circumstances affect the identification of the target group, and the mass killing is legitimized among the perpetrators as revenge (Dutton et al., 2005: 470). Often, mass killings are the result of feared future conflict, and rapid social change is frequently behind the perception of a threat that must be eliminated. When indiscriminate 
killing takes place (e.g. of children), the actions are often justified on the basis that the target group poses a future threat. A plausible alternative (or additional) motive can be to cause terror through the ruthless killing of vulnerable individuals. The excessive violence commonly witnessed in massacres (mutilations, rape, torture, and killing of defenceless victims) differs from the violence often seen in genocides, where the violence is 'dispassionate' and 'instrumental' (since the violence is carried out by those who only execute orders) (Wolfgang, 1958; Dutton \& Kerry, 1999). Dutton et al. (2005) argue that sociopolitical circumstances may be enough to explain instrumental violence, whereas the 'passionate' killing seen in many massacres is not yet well understood. If we combine theories of modern mass killing with the efficient slaughter so far evidenced in Sandby borg, it is plausible to interpret the dispassionate killing as having been caused by sociopolitical instability. The lack of traces of overkill combined with the effective killing pattern could indicate that the individuals who carried out the slaughter were not personally involved with the victims. Possibly, the killing was ordered. Credible motives behind the massacre were likely to have been connected to experienced past injustice, the perception of the Sandby borg inhabitants as a threat, and the will to spread fear to achieve control. This hypothesis fits with the interpretation that the massacre in Sandby borg was not a raid carried out for the purposes of plundering. The motives suggested point to the attackers having been a neighbouring group (also discussed in Victor, 2015; Alfsdotter et al., 2018). Though a 'personal' scenario cannot be verified based on the current analysis, and remains speculative, the unburied bodies appear to signal a provoking motive. They could be seen as a final act of violence, and even that the entire community was wiped out. The finds at Sandby borg strengthen the perception of the Migration period on Öland as a socially turbulent time, probably involving strife with conflicting groups of inhabitants.

The proposed mass killing at Sandby borg can be contrasted with the image of warfare associated with finds such as the weapon deposits in Hjortspring and Nydam in Denmark (see Supplementary Material 1). The weapon offerings are deposited in an organized and orchestrated form, demonstrating control and power in relation to the contemporary narrative and ideology. At Sandby borg, the grim result and reality of violence is evident.

\section{SuMMING UP}

Archaeological excavations have revealed evidence of a Migration-period massacre in the ringfort of Sandby borg on Öland. Thus far, the remains of twenty-six individuals have been found in several houses and on the surrounding street outside them. Perimortem sharp, blunt, and penetrating trauma consistent with interpersonal violence was identified in eight individuals (31 per cent of the assemblage). In addition, the locations and skeletal positions of the remaining individuals imply that they were killed in the same event. The victims belonged to all age groups, from infants to individuals over 50 years of age. However, only men have been identified so far. The perpetrators were seemingly numerous and coordinated. The assault was carried out expediently, judging from the efficient distribution of trauma, the absence of body modification, and the fact that items of value still remain. Though most injuries were located on the skulls, a clear trauma pattern could not be established. The identified weapon types are consistent with contemporary weapons. The prevailing sociopolitical situation is 
likely to have led to social stress. It is hypothesized that the decision to kill the Sandby borg inhabitants was based on a feeling of past injustices and a perception of the Sandby borg group as a threat. The killing of children is indicative of a fear of retribution among the attackers. Ultimately, the motive behind the massacre was probably to attain regional power and control.

\section{ACKNowledgements}

This work was supported by the Riksbankens jubileumsfond under Grant P150138:1, the Knowledge Foundation, Bohusläns Museum, and Linnaeus University through the Graduate School in Contract Archaeology (GRASCA). The present article builds on osteological analysis conducted by Alfsdotter and on excavation records by Victor, Papmehl-Dufay, Gunnarson, Alfsdotter, and colleagues. We would like to thank the anonymous reviewers for helpful comments and suggestions. Many thanks to Tim Sandusky and Dejan Gajic for language review, and to Anders Högberg for comments on an earlier version of the manuscript. We also thank Daniel Lindskog and Helena Victor for providing photographs and illustrations.

\section{REFERENCES}

Alfsdotter, C. in press. Humanosteologi i Sandby borg. In: L. Papmehl-Dufay \& H. Victor, eds. Sandby borg IX. Undersökningar 2016, Sandby sn, Mörbylånga kommun, Öland. Report prepared for Kalmar läns museum.

Alfsdotter, C. \& Kjellström, A. in preparation. A Taphonomic Interpretation of the Postmortem Fate of the Victims Following the Mass Killing at Sandby Borg.

Alfsdotter, C., Papmehl-Dufay, L. \& Victor, H. 2018. A Moment Frozen in Time:
Evidence of a Late Fifth-Century Massacre at Sandby Borg. Antiquity, 92: 421-36. https://doi.org/10.15184/aqy.2018.21

Andrushko, V.A., Latham, K.A.S., Grady, D.B., Pastron, A.G. \& Walker, P.L. 2005. Bioarchaeological Evidence for Trophy Taking in Prehistoric Central California. American Journal of Physical Anthropology, 127: 375-84. https://doi.org/10.1002/ajpa. 20044

Bennike, P. 1998. De faldne fra Krigergravenanalys af skeletterne fra Sandbjerget. Liv og Lern, 12: 14-21.

Berryman, H.E. \& Symes, S.A. 1998. Recognizing Gunshot and Blunt Cranial Trauma Through Fracture Interpretation. In: K. Reichs, ed. Forensic Osteology. Springfield (IL): Charles C. Thomas, pp. 333-52.

Boylston, A. 2000. Evidence for WeaponRelated Trauma in British Archaeological Samples. In: M. Cox \& S. Mays, eds. Human Osteology in Archaeology and Forensic Science. London: Greenwich Medical Media, pp. 357-80.

Buikstra, J.E. \& Ubelaker, D.H. 1994. Standards for Data Collection from Human Skeletal Remains: Proceedings of a Seminar at the Field Museum of Natural History. Fayetteville (AR): Arkansas Archaeological Survey.

Büntgen, U., Tegel, W., Nicolussi, K., McCormick, M., Frank, D., Trouet, V. et al. 2011. 2500 Years of European Climate Variability and Human Susceptibility. Science, 331: 578-82. https://doi.org/10.1126/science.1197175

Cameron, C.M. 2013. How People Moved Among Ancient Societies: Broadening the View. American Anthropologist, 115: 218-31. https://doi.org/10.1111/aman. 12005

Dolinak, D., Matshes, E. \& Lew, E. 2005. Forensic Pathology. Principles and Practice. Burlington (MA): Elsevier.

Dutton, D.G. \& Kerry, G. 1999. Modus Operandi and Personality Disorder in Incarcerated Spousal Killers. International Journal of Law and Psychiatry, 22: 287300. https://doi.org/10.1016/S0160-2527 (99)00010-2

Dutton, D.G., Boyanowsky, E.O. \& Bond, M.H. 2005. Extreme Mass Homicide: From Military Massacre to Genocide. Aggression and Violent Behavior, 
10: 437-73. https://doi.org/10.1016/j.avb. 2004.06.002

Ember, C.R. \& Ember, M. 1997. Violence in the Ethnographic Record: Results of Cross-Cultural Research on War and Aggression. In: D.L. Martin \& D.W. Frayer, eds. Troubled Times: Violence and Warfare in the Past. Amsterdam: Gordon and Breach, pp. 1-20.

Fibiger, L. 2014. Misplaced Childhood? Interpersonal Violence and Children in Neolithic Europe. In: C. Knüsel \& M. Smith, eds. The Routledge Handbook of the Bioarchaeology of Human Conflict. Abingdon: Routledge, pp.127-45.

Fischer, S. 2005. Roman Imperialism and Runic Literacy: The Westernization of Northern Europe (150-800 AD) (Aun 33). Uppsala: Department of Archaeology and Ancient History, Uppsala University.

Geber, J. 2015. Comparative Study of Perimortem Weapon Trauma in Two Early Medieval Skeletal Populations (AD 400-1200) from Ireland. International Journal of Osteoarchaeology, 25: 253-64. https://doi.org/10.1002/oa.2281

Gunnarsson, F., Victor, H. \& Alfsdotter, C. 2016. Sandby borg VII. Undersökningar 2015, Sandby sn, Mörbylånga kommun, Öland. Kalmar: Kalmar läns museum.

Guyomarch, P., Campagna-Vaillancourt, M., Kremer, C. \& Sauvageau, A. 2010. Discrimination of Falls and Blows in Blunt Head Trauma: A Multi-Criteria Approach. Journal of Forensic Sciences, 55: 423-27. https://doi.org/10.1111/j.15564029.2009.01310.x

Heather, P.J. 2006. The Fall of the Roman Empire: A New History of Rome and the Barbarians. Oxford \& New York: Oxford University Press.

Hedeager, L. 2011. Iron Age Myth and Materiality: An Archaeology of Scandinavia $A D$ 400-1000. London: Routledge.

Heimdahl, J. 2014. Makroskopisk analys 2014. In: H. Victor, ed. Sandby borg IV. Undersökningar 2014. Sandby socken, Mörbylånga kommun, Öland. Kalmar: Kalmar läns museum, pp. 399-401.

Heimdahl, J. 2016. Växtmakrofossilanalyser. In: L. Papmehl-Dufay \& C. Alfsdotter, eds. Sandby borg $V$. Ögonblicket under markytan. Seminarieundersökning $i$ Sandby borg 2014. Sandby sn, Öland. Kalmar: Kalmar läns museum, pp. 50-51.
Hsiang, S.M., Burke, M. \& Miguel, E. 2013. Quantifying the Influence of Climate on Human Conflict. Science, 341: 6151. https://doi.org/10.1126/science.1235367

Ingelmark, B.E. 1939. The Skeletons. In: B. Thordeman, ed. Armour from the Battle of Wisby 1361. Stockholm: Kungliga Vitterhets Historie och Antikvitets Akademien, pp. 149-209.

Kjellström, A. 2005. A Sixteenth-Century Warrior Grave from Uppsala, Sweden: The Battle of Good Friday. International Journal of Osteoarchaeology, 15: 23-50. https://doi.org/10.1002/oa.746

Kjellström, A. \& Hamilton, M. 2014. The Taphonomy of Maritime Warfare: A Forensic Reinterpretation of Sharp Force Trauma from the 1676 Wreck of the Royal Swedish Warship Kronan. In: D.L. Martin \& C.P. Anderson, eds. Bioarchaeological and Forensic Perspectives on Violence. How Violent Death is Interpreted from Skeletal Remains. Cambridge: Cambridge University Press, pp. 34-50.

Knüsel, C.J. 2005. The Physical Evidence of Warfare: Subtle Stigmata? In: M. Parker Pearson \& I.J.N. Thorpe, eds. Warfare, Violence, and Slavery (British Archaeological Reports International Series 1374). Oxford: Archaeopress, pp. 49-65.

Kohler, T.A. \& Kramer Turner, K. 2006. Raiding for Women in the Pre-Hispanic Northern Pueblo Southwest? Current Anthropology, 47: 1035-45. https://doi.org/ 10.1086/508697

Kremer, C. \& Sauvageau, A. 2009. Discrimination of Falls and Blows in Blunt Head Trauma: Assessment of Predictability Through Combined Criteria. Journal of Forensic Science, 54: 923-26. https://doi. org/10.1111/j.1556-4029.2009.01072.x

Larsen, C.S. 1999. Bioarchaeology: Interpreting Behavior from the Human Skeleton (2nd ed). New York: Cambridge University Press.

Lindbom, P. 2006. Vapnen under Wreccornas tid, 150-500 e.Kr. Uppsala: Department of Archaeology and Ancient History, Uppsala University.

Lund Hansen, U. 1987. Römischer Import im Norden. Warenaustausch zwischen dem Römischen Reich und dem freien Germanien während der Kaiserzeit unter besonderer Berücksichtigung Nordeuropas. Kopenhagen: Kongelige Nordiske Oldskriftselskab. 
Magnus, B. 1997. The Firebed of the Serpent: Myth and Religion in the Migration Period Mirrored Through Some Golden Objects. In: L. Webster \& M. Brown, eds. The Transformation of the Roman World AD 400-900. London: British Museum Press, pp. 194-207.

Magnus, B. 2002. Ørnen flyr - om stil I i Norden. In: K. Høilund Nielsen, ed. Nordeuropaisk dyrestil 400-1100 e.kr (Hikuin 29). Højbjerg: Hikuin, pp. 105-19.

Martin, D.L. \& Harrod, R.P. 2015. Bioarchaeological Contributions to the Study of Violence. American Journal of Physical Anthropology, 59: 116-45. https:// doi.org/10.1002/ajpa.22662

Martin, D.L., Harrod, R.P. \& Fields, M. 2010. Beaten Down and Worked to the Bone: Bioarchaeological Investigations of Women and Violence in the Ancient Southwest. Landscapes of Violence, 1: 119.

McCall, G. \& Shields, N. 2008. Examining the Evidence from Small-Scale Societies and Early Prehistory and Implications for Modern Theories of Aggression and Violence. Aggression and Violent Behavior, 13: 1-9. https://doi.org/10.1016/j.avb. 2007.04.001

Mejsholm, L. 2009. Gränsland: konstruktion av begravningsritual och tidig barndom vid tiden för kristnandet $i$ Skandinavien (Occasional Papers in Archaeology 44). Uppsala: Uppsala University.

Näsman, U. 1984. Glas och handel i senromersk tid och folkvandringstid: en studie kring glas frän Eketorp-II, Oland, Sverige. Uppsala: Department of Archaeology and Ancient History, Uppsala University.

Näsman, U. 1988. Den folkvandringstida krisen i Sydskandinavien, inklusive Öland och Gotland. In: U. Näsman \& J. Lund, eds. Folkevandringstiden $i$ Norden: en krisetid mellem aldre og yngre jernalder:rapport fra et bebyggelsearkcologisk forskersymposium i Degerhamn, Öland, d. 2-4 oktober 1985. Aarhus: Universitetsforlag, pp. 227-55.

Nicklasson, P. 1997. Svärdet ljuger inte (Acta Archaeologica Lundensia 4. 22). Stockholm: Almqvist \& Wiksell International.

Novak, S. 2000. Battle-Related Trauma. In: V. Fiorato, A. Boylston \& C. Knüsel, eds. Blood Red Roses: The Archaeology of a Mass Grave from the Battle of Towton AD 1461. Oxford: Oxbow Books, pp. 90-102.
Owsley, D.W., Berryman, H.E. \& Bass, W.M. 1977. Demographic and Osteological Evidence for Warfare at the Larson Site, South Dakota. Plains Anthropologist, 22: 119-31. https://doi.org/10.1080/2052546. 1977.11908859

Papmehl-Dufay \& C. Alfsdotter, eds. Sandby borg $V$. Ögonblicket under markytan. Seminarieundersökning $i$ Sandby borg 2014. Sandby sn, Öland. Kalmar: Kalmar läns museum.

Reichs, K.J. 1998. Postmortem Dismemberment: Recovery, Analysis and Interpretation. In: K.J. Reichs, ed. Forensic Osteology: Advances in the Identification of Human Remains. Springfield (IL): Charles C. Thomas, pp. 353-88.

Sanderson, S.K. 2014. Human Nature and the Evolution of Society. Boulder (CO): Westview Press.

Šlaus, M., Novak, M., Vyroubal, V. \& Bedić, Ž. 2010. The Harsh Life on the 15th Century Croatia-Ottoman Empire Military Border: Analyzing and Identifying the Reasons for the Massacre in Čepin. American Journal of Physical Anthropology, 141: 358-72. https:// doi.org/10.1002/ajpa.21152

Stenberger, M. 1933. Öland under äldre järnåldern: en bebyggelsehistorisk undersökning. Uppsala: Royal Academy of Letters, History and Antiquities.

Tegtmeyer, C. \& Martin, D.L. 2017. The Bioarchaeology of Women, Children, and Other Vulnerable Groups in Times of War. In: D.L. Martin \& C. Tegtmeyer, eds. Bioarchaeology of Women and Children in Times of War. Cham: Springer International, pp. 1-14.

Timmins, S., Seréville-Niel, C. \& Brickley, M. 2017. Childhood Cranial Trauma from a Late Roman and Merovingian Context from Michelet, Lisieux, France. International Journal of Osteoarchaeology, 27: 715-22. https://doi.org/10.1002/oa.2581

Ubelaker, T.H. 2015. The Concept of Perimortem in Forensic Science. In: K. Gerdau-Radonvić \& K. McSweeney, eds. Trends in Biological Anthropology, 1. Oxford: Oxbow Books, pp. 93-99.

Vargová, L., Horáčková, L., Horáková, M., Eliášová, H., Myšková, E. \& Ditrich, O. 2016. Paleopathological, Trichological and Paleoparasitological Analysis of Human Skeletal Remains from the Migration Period Cemetery Prague-Zličín. Interdisciplinaria Archaeologica, 7: 13-32. 
Viberg, A. 2012. Remnant Echoes of the Past: Archaeological Geophysical Prospection in Sweden (Theses and Papers in Scientific Archaeology 13). Stockholm: Stockholm University.

Victor, H. 2015. Sandby borg: ett fruset ögonblick under folkvandringstiden. In: K-H. Arnell \& L. Pamphell-Dufay, eds. Grävda minnen: Från skedemosse till Sandby borg (Meddelanden från Kalmar läns hembygdsförbund och Stiftelsen Kalmar läns museum årgång 95). Kalmar: Kalmar läns museum, pp. 97-115.

Waddington, C., Beswick, P., Brightman, J., Bronk Ramsey, C., Burn, A., Cook, G., et al. 2012. Excavations at Fin Cop, Derbyshire: An Iron Age Hillfort in Conflict? Archaeological Journal, 169: 159-236. https:// doi.org/10.1080/00665983.2012.11020914

Wilhelmson, H. 2017. Perspectives from a Human-Centred Archaeology: Iron Age People and Society on Öland (Acta Archaeologica Lundensia 68). Lund: Department of Archaeology and Ancient History, Lund University.

Willey, P. 1990. Prehistoric Warfare on the Great Plains: Skeletal Analysis of the Crow Creek Massacre Victims. New York: Garland Publishing.

Wolfgang, M. 1958. Patterns of Criminal Homicide. Philadelphia (PA): University of Pennsylvania.

\section{SupPlementary Material}

To view supplementary material for this article, please visit https://doi.org/10.1017/ eaa.2018.55.

\section{Biographical Notes}

Clara Alfsdotter is an osteologist and archaeologist at Bohusläns Museum. She is currently working on her $\mathrm{PhD}$ at Linnaeus University's Graduate School in Contract Archaeology (GRASCA). Her research focuses on the treatment of dead bodies. She has a special interest in the social implications of violence, death, and taphonomy.

Address: Clara Alfsdotter, Linnaeus University, School of Cultural Studies, Faculty of Arts and Humanities, Linnégatan 5, SE-391 82 Kalmar, Sweden. [email: Clara.Alfsdotter@bohuslansmuseum.se].

ORCID: https://orcid.org/0000-00020181-4458.

Anna Kjellström is Associate Professor in Osteology at the Department of Archaeology, Stockholm University. She is currently a member of the Atlas Project, dealing with ancient human genomes. She has specialized in human health issues and trauma in skeletal populations from the Mesolithic to modern times, with a particular interest in the Viking period and Early Middle Ages. Her research focuses on bioarchaeological response associated with sociocultural concepts such as urbanization, interpersonal violence, and subjugated groups.

Address: Archaeological Research Laboratory, Department of Archaeology and Classical Studies, University of Stockholm, Lilla Frescativägen 7, SE-106 91 Stockholm, Sweden. [email: Anna.Kjellstrom@ ofl.su.se]. ORCID: https://orcid.org/ 0000-0001-8964-3771.

\section{Le massacre de Sandby borg : violence interpersonnelle et profil démographique des morts}

Les restes de 26 personnes dépourvues de sépultures ont été découverts dans les fouilles de l'enclos fortifié de Sandby Borg (datant de l'àge du Fer, 400-550 apr. J.-C.), aussi bien à l'extérieur qu'à l'intérieur 
de leurs maisons. Les squelettes ainsi que les données archéologiques indiquent que le site a été abandonné après la mort de ces individus. L'étude des ossements humains et une analyse des traumatismes subis a suivi les protocoles établis en anthropologie physique. L'examen des ossements n'a identifié que des sujets mâles; en revanche, toutes les classes d'âge étaient représentées. Huit individus (31 pour cent de l'ensemble) présentaient des signes de traumatisme périmortem de divers types (lésions causées par des instruments tranchants, contondants ou pénétrants) que l'on peut interpréter comme indices de violence interpersonnelle. La position des corps et la configuration des traumatismes laissent penser à un massacre plutôt qu'à une bataille. La manière "efficace" d'infliger une blessure (c'est-à-dire en usant de violence de manière économique mais fatale), le fait que les cadavres n'ont pas été manipulés et le contexte archéologique suggèrent que les responsables étaient nombreux et que leur assaut a été mené avec efficacité. La situation sociopolitique de l'époque était instable, ce qui nous amène à proposer que le motif de l'attaque fût l'obtention du pouvoir et du contrôle. (Translation by Madeleine Hummler)

Mots-clés: violence, traumatisme, époque de grandes migrations, Sandby borg, âge du Fer, morts sans sépultures

\section{Das Massaker von Sandby borg: interpersonale Gewalt und demografisches Profil der Toten}

Während der Ausgrabungen der eisenzeitlichen Ringwallanlage von Sandby borg (400-550 n. Chr.) sind die Überreste von 26 unbestatteten Menschen innerhalb und außerhalb der Häuser zutage gekommen. Die Skelette und die archäologischen Angaben deuten darauf hin, dass die Ringwallsiedlung nach dem Tod dieser Menschen aufgegeben worden ist. Die Untersuchung der Knochen und die Analyse der Traumata folgten die anerkannten Protokolle der biologischen Antbropologie. Die osteologische Auswertung hat nur Männer identifiziert aber alle Altersstufen waren vertreten. Acht Individuen (31 Prozent der Sammlung) hatten tödliche Verletzungen (perimortem Trauma), die von verschiedenen, scharfen, stumpfen und penetrierenden Gegenständen verursacht worden sind. Die Lage der Leichen und die Struktur der Traumata lassen eher auf ein Massaker als auf eine Schlacht schließen. Die Verteilung von "effizienten” Verletzungen (wo Gewalt spärlich aber effektiv angewendet wurde), die Tatsache, dass man die Leichen nicht nachträglich manipuliert hatte, und die archäologischen Angaben deuten darauf hin, dass die Täter zahlreich waren und dass der Angriff effektiv war. Die damalige soziopolitische Situation war offensichtlich unbeständig, was uns darauf schließen lässt, dass die Übernahme der Macht und Kontrolle der Grund für das Massaker war. (Translation by Madeleine Hummler)

Stichworte: Gewalt, Trauma, Völkerwanderungszeit, Sandby borg, Eisenzeit, unbestattet 